\title{
Description, seasonal morphological variation, and molecular identification of Paraxanthus barbiger megalopae obtained from the natural environment
}

\author{
David Ampuero $\cdot$ Alvaro T. Palma $\cdot$ David Veliz $\cdot$ \\ Luis Miguel Pardo
}

Received: 13 April 2009 / Accepted: 23 September 2009 / Published online: 6 October 2009

(C) Springer-Verlag and AWI 2009

\begin{abstract}
Larval identification represents a powerful tool for detailed studies on recruitment and population dynamics in marine invertebrates. However, intra-specific morphological variation can become a serious limitation for the correct identification at species level. High morphological variation can be expected in species with continuous breeding periods because larvae are exposed to seasonal fluctuations in physical and biological factors during their development in the plankton. We describe, for the first time, the megalopae of Paraxanthus barbiger, one of the most common and abundant brachyuran crabs along the coast of Chile. To validate larvae identification, the $16 \mathrm{~S}$ rRNA gene was sequenced from both megalopae and adults, and was compared with sequences of three sympatric species. In addition, size, body shape, and appendage setation pattern variations were analyzed with a year-round sampling scheme. The results demonstrated high seasonal phenotypic plasticity in size. Despite these differences,
\end{abstract}

Communicated by H.-D. Franke.

D. Ampuero

141 Abel Smith St, Te Aro, Wellington, New Zealand

A. T. Palma

Center for Advanced Studies in Ecology and Biodiversity (CASEB), Pontificia Universidad Católica de Chile, Alameda 340 Casilla 114-D, Santiago, Chile

D. Veliz

Instituto de Ecología y Biodiversidad (IEB), Universidad de Chile, Las Palmeras 3425 Casilla 653, Santiago, Chile

L. M. Pardo $(\square)$

Laboratorio Costero Calfuco, Instituto de Biología Marina, Universidad Austral de Chile, Casilla 567, Valdivia, Chile e-mail: luispardo@uach.cl certain conservative characteristics exist which can be very useful for identification at species level.

Keywords Chile $\cdot$ Morphological description ·

Megalopae $\cdot$ Xhantidae $\cdot 16$ S sequence

\section{Introduction}

Larval supply of meroplanktonic species is a key factor driving population dynamics, as it can determine the magnitude of recruitment (Underwood and Keough 2001). In brachyuran decapods, abundance of megalopae (larvae ready to settle) has been successfully used as an indicator of recruitment to the benthic environment (e.g. Moksnes and Wennhage 2001; Palma et al. 2006). However, one serious limitation in many such studies has usually been the lack of information available to identify the megalopae to species level.

Traditionally, the identification of larvae has been accomplished through morphological approximations obtained from larvae cultivated in the laboratory. For this, it is common to use one or few ovigerous females; an approach that does not account for the expected natural variation in morphological features of larvae from the natural environment (Ingle 1992). It is likely that important factors in the planktonic environment, such as temperature, salinity, food availability, or predation pressure exhibit variability likely to affect larval morphology (Anger 2001; Hadfield and Strathmann 1996). In fact, Shirley et al. (1987) reported morphological differences in zoea larvae of Cancer magister (Dana, 1852) collected in Alaskan and Californian waters, localities exhibiting distinct and contrasting oceanographic conditions. Furthermore, important variability in larval features has been described for other decapod species (i.e. Betaeus, Crangon and Neohelice), which have been 
related to the availability of different food types and temperature regimes (Bas et al. 2008; Wehrtmann 1994; Wehrtmann and López 2003). Seasonal and local morphological variations have also been found in megalopae of Cancer crabs. Orensanz and Gallucci (1988) and DeBrosse et al. (1990) found differences in size, appendage setation pattern, and timing of settlement in megalopae of C. magister from offshore and inshore populations. Pardo et al. (2009) recorded greater sizes in megalopae of C. setosus collected during the autumn as compared with those from spring collections. A similar pattern of seasonal size variation has been detected in other groups of decapods, such as anomuran megalopae (Gebauer et al. 2007).

Studies on the larval morphology of brachyuran crustaceans along the South East Pacific coast of the Americas are scarce. This constitutes one of the main shortcomings in recruitment studies at the species level in the region (Wehrtmann and Báez 1997). This knowledge gap is even greater for the final megalopae stages given the difficulties of cultivation and the high mortality associated with metamorphosis (Pohle et al. 1999; Wehrtmann and Báez 1997).

In this study, the megalopae of one of the most abundant crab species in the shallow subtidal environment along the coast of Chile, Paraxanthus barbiger (Poeppig 1836) (Palma et al. 2003a, b, 2006; Pardo et al. 2007), is described for the first time. This species is distributed from Callao, Perú to Chonos archipelagos $\left(48^{\circ} \mathrm{S}\right)$ (Retamal 1981) sharing his habitats with, at least, eight more xanthoid species across to Chilean coast (Lancellotti and Vásquez 2000). Several of them, such as Gaudichaudia gaudichaudii (H. Milne Edwards, 1834) Homalaspis plana (H. Milne Edwards, 1834) and Pilumnoides perlatus (Poeppig, 1836), overlap an important extension of their geographic distribution with $P$. barbiger and, although less abundant, also occur in high numbers in the same habitat (Palma et al. 2003a, b, 2006). Therefore, adequate descriptions with species-specific diagnostic features are necessary for the correct and unambiguous identification of individuals.

In contrast to traditional descriptions, the megalopae sampled for this study were obtained from their natural environment and, like other studies in crustacean larvae, specific identification was made using molecular tools (i.e. Makinster et al. 1999; Pardo et al. 2009). Larvae were obtained from a year-round sampling program; therefore, a morphological comparison of larvae from different seasons was possible.

\section{Materials and methods}

\section{Collection of the megalopae}

The study was carried out at Punta de Tralca $\left(33^{\circ} 25^{\prime} \mathrm{S}\right.$, $71^{\circ} 42^{\prime} \mathrm{W}$ ), a protected bay located on the central coast of
Chile. Megalopae were obtained from under boulders and shell hash substrata by means of an air-lift-suction device manipulated by divers (Wahle and Steneck 1991) at depths between 8 and $10 \mathrm{~m}$. At least four frames of $0.25 \mathrm{~m}^{2}$ were sampled bimonthly between May 2004 and May 2005. The content of each quadrant was collected inside $1 \mathrm{~mm}$ mesh bags attached to the end of the suction sampler.

\section{Larval description}

A total of 20 megalopae were dissected in glycerine on microscope slides under a stereo-microscope in order to describe in detail the general larval morphology, including their appendages. The figures were made using a drawing tube mounted on a Zeiss AXIOSKOP microscope. The diagnosis was made following that proposed by Clarke et al. (1998).

Variation in larval morphometry was recorded by measuring the length and width of the carapace under a binocular microscope for all megalopae collected. Seasonal variation in size was analyzed utilizing a one-way ANOVA. Multiple comparisons were performed using an LSD test. In addition, 180 individuals from different months $(12 / 05 / 2004$, $n=11 ; 16 / 09 / 2004, n=23 ; 22 / 11 / 2004, n=317 ; 02 / 02 /$ $2005, n=133 ; 05 / 04 / 2005, n=1 ; 25 / 04 / 2005, n=5 ; 15 / 07 /$ $2005, n=7$ ) were examined in order to describe the variation in the appendage setation pattern.

\section{Molecular validation}

Since larvae were obtained in the field, a molecular corroboration was necessary to avoid error in the species identification. To achieve this, nine larvae chosen randomly from different sampling dates and two adults of $P$. barbiger were stored in $95 \%$ ethanol. Larvae and a small sample of muscle tissue from the adults were used to extract DNA using the protocol described by Aljanabi and Martinez (1997). Following PCR conditions described by Mantelatto et al. (2007), a partial region of the 16S rRNA gene was amplified using the primers: 16Sar ( $5^{\prime}$-GCCTGTTTATCAAAAAC AT- $\left.3^{\prime}\right)$ and 16Sbr (5'-CCGGTCTGAACTCAGATCAC GT-3'). Both primers were described by Palumbi (1996) and modified by Schubart et al. (2000). PCR products were cleaned using QIAQuick columns (QIAGen, Canada) and sequencing performed with Macrogen Inc (http://www. macrogen.com). Later, sequences were aligned by eye using the ProSeq v.2.9 software (Filatov 2002), and all haplotype material was deposited in Genbank.

To determine the similarities between the DNA sequences of both larvae and adult crabs, a neighbor-joining (NJ) based analysis was performed with Mega 4.0 software (Tamura et al. 2007) and the consistency of each branch was tested using a bootstrap of 10,000 replicates. Because 
other species of the Family Xanthidae and related families are present along the Chilean coast, and in order to avoid potential confusion with them, the NJ tree was constructed using sequences obtained from several adults collected from Bahía Corral, Chile $\left(39^{\circ} 49^{\prime} \mathrm{S}, 7^{\circ} 14^{\prime} \mathrm{W}\right)$. These were Paraxhantus barbiger (Accession Numbers: FJ031221 to FJ031225), Gaudichaudia gaudichaudii (Genbank Accession Number: FJ687222 to FJ687224), Homalaspis plana (Genbank Accession Number: FJ687226 and FJ687227) and Pilumnoides perlatus (Genbank Accession Number: FJ687225). Through this method, megalopae identified as Paraxanthus barbiger could be grouped with conspecific adults.

\section{Results}

\section{Morphological description of Paraxanthus barbiger megalopae}

Cephalothorax (Fig. 1a) Length $(2.8 \pm 0.14 \mathrm{~mm}) /$ width $(2.2 \pm 0.11 \mathrm{~mm})$. Ratio of 1,3 . Narrows anteriorly with a smooth rostrum except for a small groove in the middle. 46 surface and 58 ventral marginal simple setae.

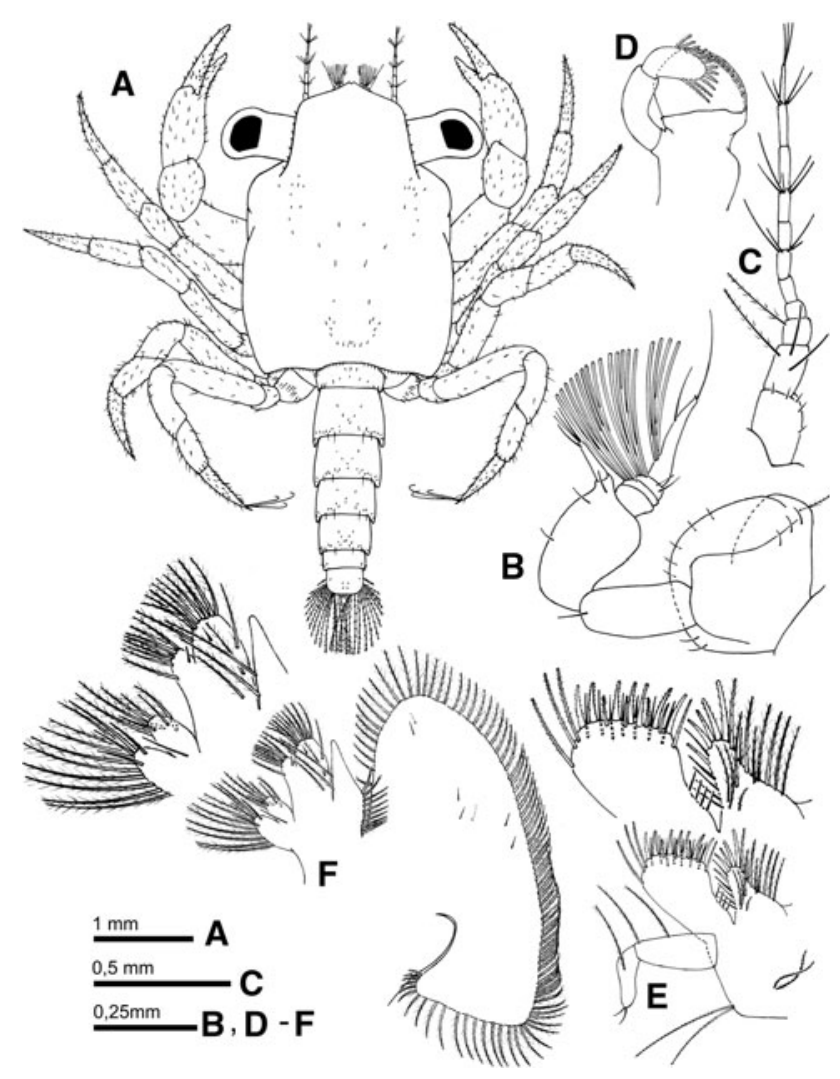

Fig. 1 Paraxanthus barbiger megalopa; a dorsal view, b antennule, c antenna, $\mathbf{d}$ mandible, e maxillule, $\mathbf{f}$ maxilla
Antennule (Fig. 1b) Peduncle 3-segmented, with 10,1,3 simple setae plus 1 plumose seta on the proximal segment. Endopod non-segmented with 1 subterminal and 3 terminal simple setae; exopod 4-segmented with a setation pattern of 0,8,6,4 aesthetascs and 0,0,2,1 simple setae, plus 1 long terminal plumose seta on the distal segment.

Antenna (Fig. 1c) Peduncle 3-segmented with 5,2,0 simple and $0,1,1$ plumose setae. Flagellum composed of $0,0,4,0,5,0,4,3$ simple setae.

Mandible (Fig. 1d) Developed outer blade surface; palp 3 -segmented with 12 plumodenticulate cuspidate setae on the distal segment.

Maxillule (Fig. 1e) Coxal endite with 10 plumose, 5 plumodenticulate cuspidate and 6 simple setae; basial endite with 15 plumodenticulate cuspidate plus 11 simple setae, of which 7 are subterminal and 4 are located on the interior basal margin. Endopod 2-segmented with 2, 3 simple setae. Base of the maxillule with 2 plumodenticulate cuspidate and 2 plumose setae.

Maxilla (Fig. 1f) Coxal endite bilobed; proximal and distal lobes with 13 (10 plumose, 3 simple) and 8 (6 plumose, 2 simple) setae, respectively. Basial endite bilobed; proximal and distal lobes of the basial endite with 9 (8 plumose, 1 simple) and 14 (13 plumose, 1 simple) setae. Endopod unsegmented with 12 plumose marginal setae. Scaphognathite with 86-89 plumose marginal setae and 7 simple setae on the interior surface.

First maxilliped (Fig. 2a) Anterior portion of the epipod triangular in shape, with 3 long setae on the external margin and 2 plumodenticulate cuspidate setae on the base. The posterior portion has an elongated shape, with 14 long marginal simple setae. Coxal endite with 3 plumose, 15 plumodenticulate cuspidate and 2 simple setae; basial endite with 27 plumodenticulate cuspidate, 8 plumose and one simple setae. Endopod unsegmented with 2 plumose setae in the middle of the internal margin and 6 simple setae on the terminal margin; exopod 2-segmented with 2,5 plumose setae.

Second maxilliped (Fig. 2b) Epipod with 12 long setae. Gill between the epipod and exopod. Endopod 4-segmented with $0,2,3,4$ plumodenticulate cuspidate setae, plus 7 plumose and 5 simple setae in the proximal segment; exopod 2 -segmented, with 3 setae in the proximal segment and 5 plumose setae on the distal segment. Protopod with a pair of plumodenticulated and 3 marginal simple setae, plus 2 plumose setae close to the base of the exopod.

Third maxilliped (Fig. 2c) Epipod with 30 long and 8 plumose setae close to the base; protopod with 22 plumose setae. Endopod 5-segmented with 33,18,16,16,12 setae, mainly plumodenticulate cuspidate. Exopod 2-segmented 


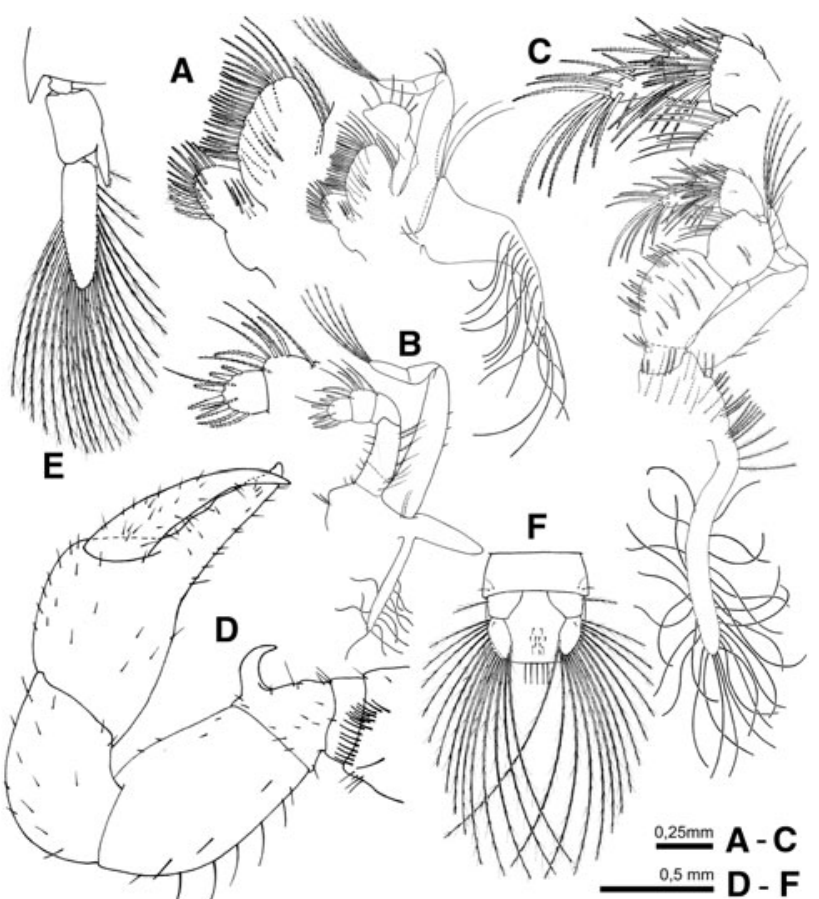

Fig. 2 Paraxanthus barbiger megalopa; a first maxilliped, b second maxilliped, $\mathbf{c}$ third maxilliped, $\mathbf{d}$ cheliped, e second pleopod, $\mathbf{f}$ telson

with 5 setae on the outer margin of the proximal segment, and 7 plumose setae on the distal segment.

Chelipeds (Fig. 2d) Surface covered by a large number of simple setae. Exhibits a prominent hook-like spine on the internal margin of the isquium. Internal chela fixed with shallow denticulation.

Pereiopods (Fig. 1a) Well developed with the surface covered mainly by simple setae. Fifth pereiopod with 3 terminal large setae on the dactylus.

Abdomen (Fig. 1a) Composed of 6 segments plus the telson; with 16, 28, 26, 20, 22, 4 simple setae. The second and fifth segments pose biramous pleopods, with an exopod displaying 23 long plumose setae and an endopod with 4-5 concinnuli (Fig. 2e); the sixth segment has a pair of uniramous uropods, where the propod presents $0-2$ plumose setae and the exopod 11-14 long plumose setae.

Telson (Fig. 2f) Posterior margin semi-rounded with 6 simple setae on the dorsal surface, $6-7$ on the ventral, plus 5 spines on the central posterior margin.

\section{Variation}

The number of $P$. barbiger megalopae examined $(N=296)$ was sufficient to reveal a seasonal difference in size. Significant differences were found in the length of the carapace during spring (November), summer (February) and winter

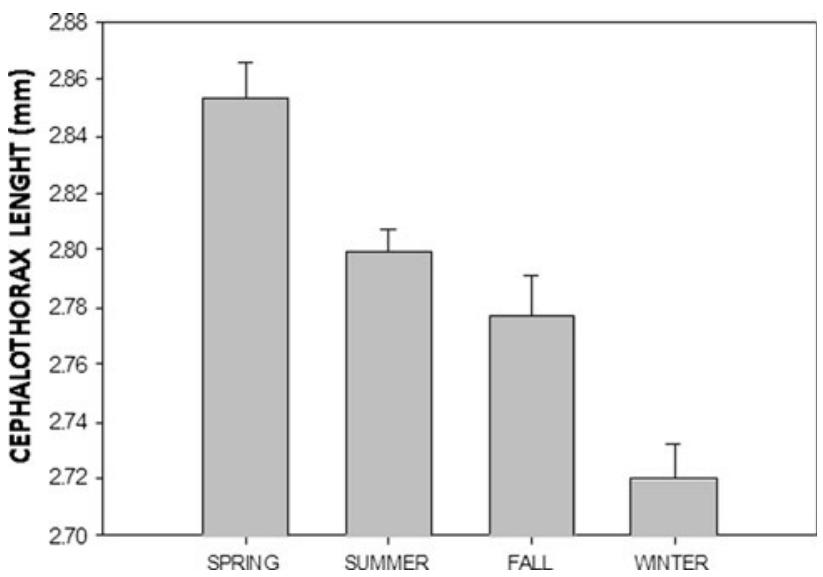

Fig. 3 Seasonal variation of mean megalopae cephalotorax length of $P$. barbiger, collected in the field

(July) $\left(F_{3,292}=7.9, P<0.001\right)$, with the spring and winter megalopae being the largest and the smallest in size, respectively. No significant differences were observed in autumn with respect to the other seasons (Fig. 3).

Setation variation is observed in some appendages, regardless of the season. Analyzed cincinnulis on the endopods $(n=90)$, despite of being known as a conservative character (Clarke et al. 1998), exhibited some degree of variations. On the second pair, there were generally 4 cincinnuli, except on some occasions when there were 5 (7 times on the left and 4 times on the right). With the third pleopod, the results were similar, five hooks were found on the right endopod of only six individuals and on the left endopod in only two. A more detailed analysis was carried out on the protopod and exopod of the uropods $(n=180)$, wherein a high frequency of variations was observed. Almost all of these individuals displayed one plumose seta on the protopod, just one exhibited two plumose setae. The exopod, on the other hand, presented 9 distinct combinations in the number of plumose setae, although the difference between the left and the right appendage was always one. Others traits such as cephalothorax and rostrum shape and the hook-like spine on the isquium of chelipeds appear invariant.

Finally, the 559 bp sequenced from the 16S rRNA gene from different species of the Family Xanthidae present in Chile showed clear molecular differences among them (Fig. 4). The bootstrap support from the NJ analysis presented a high level of consistency among branches (bootstrap support $=100$ ) showing clear molecular differences among species and grouping both megalopae described here and Paraxanthus barbiger sequences without ambiguity.

Among $P$. barbiger sequences, no insertions or deletions were detected and all mutations were transitional steps (A-G). Five haplotypes were found with a maximum of 3 mutational steps between them, with both megalopae and 


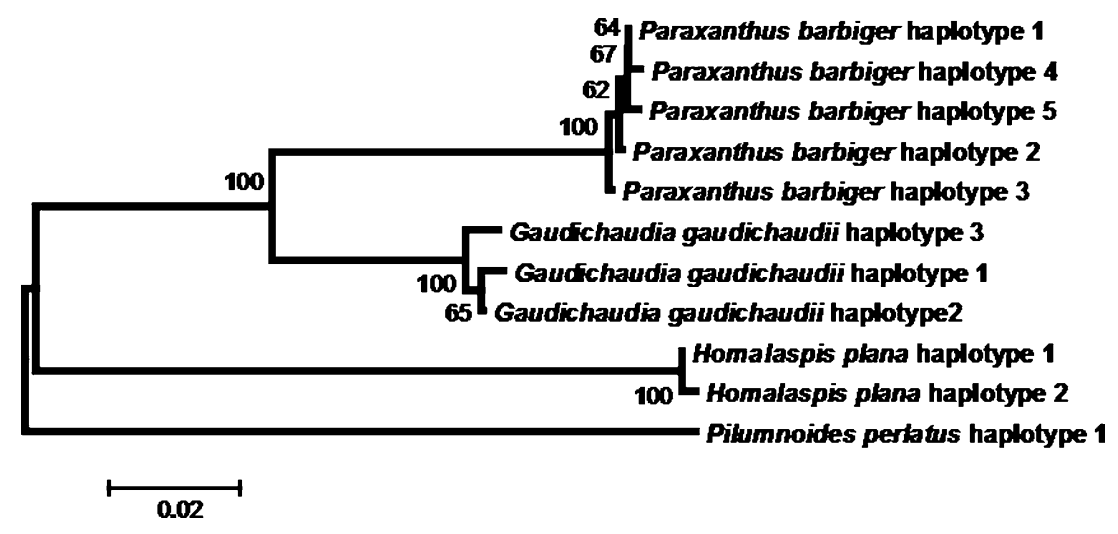

Fig. 4 Neighbor-joining tree analysis of the 16S rRNA sequences for four Chilean brachyuran species. The number at the tree nodes indicates the bootstrap values from 10,000 replicates. Five haplotypes were observed for $P$. barbiger: Haplotype 1 included one adult from March and one megalopa and adults from December; Haplotype 2: two

adults sharing the haplotype 1 . Overall, this evidence demonstrates a clear difference among species of the Family Xanthidae and a high molecular similarity among megalopae and adults of $P$. barbiger.

\section{Discussion}

It is almost impossible to recognize a species without an adequate morphological description, and this is particularly true for the early ontogenetic stages of meroplanktonic species. To this end, the current study is the first description of the megalopae of Paraxanthus barbiger. It represents an aid for future ecological studies on recruitment dynamics of the most abundant brachyuran species in the subtidal rocky shore environment along the coast of central Chile (Palma et al. 2006). In addition, the molecular corroboration of the species identity avoids any vagueness in the identification (Fig. 4).

Unlike traditional descriptions, which are usually based on the observation of some individuals maintained in the laboratory, this description was achieved by considering individuals collected year-round directly from the natural environment, thus taking into account the natural phenotypic plasticity of larvae. Such an approach allows for the quantification of intra-specific morphological variation of the megalopae of $P$. barbiger. Despite some variation detected in the number of setae on the uropods, maxilla and telson; and in the cincinnulis of the pleopods; the most evident morphological variability was in the cephalothorax size of magalopae. Indeed, conversely to the seasonal effects on size, the setation variation shows itself as conservative (Table 1), which has also been seen in other field collected brachyurans (Cuesta et al. 2002; DeBrosse et al. 1990; Guerao et al. 2006). Other traits such as rostrum megalopae from May; Haplotype 3: one megalopa from June and one from November; Haplotype 4: one megalopa from October and Haplotype 5: one megalopa from August. All haplotypes of G. gaudichaudii, $P$. perlatus and $H$. plana were sequenced from adults

Table 1 Summary of the significant morphological variations observed in the body structures of $P$. barbiger megalopae at Punta de Tralca

\begin{tabular}{llll}
\hline Structure & $\begin{array}{l}\text { Seasonal } \\
\text { variation }\end{array}$ & $\begin{array}{l}\text { Observed } \\
\text { range }\end{array}$ & $\begin{array}{l}\text { Most } \\
\text { frequent } \\
\text { value }\end{array}$ \\
\hline $\begin{array}{l}\text { Cephalothorax } \\
\text { Length (mm) }\end{array}$ & Yes & $2.66-3.60$ & 2.8 \\
$\quad$ Width (mm) & & $2.00-2.96$ & 2.2 \\
Maxilla & No & $86-89$ & 88 \\
$\begin{array}{l}\text { Scaphognathite } \\
\text { marginal setae }\end{array}$ & & & \\
Pleopods & No & $4-5$ & 4 \\
$\quad$ Cincinnuli & & $11-14$ & 13 \\
Uropods & No & $0-2$ & 1 \\
$\begin{array}{l}\text { Exopod setae } \\
\text { Protopod setae }\end{array}$ & No & $6-7$ & 6 \\
$\begin{array}{l}\text { Telson } \\
\text { Ventral setae }\end{array}$ & No & & \\
\hline
\end{tabular}

shape and the hook-like spine on the isquium of chelipeds appear invariant, making them ideal as an "easy to locate" key character of identification (e.g. Pardo et al. 2009).

In other species of the family Xanthidae, for example in Homalaspis plana, which shares most part of its distribution with P. barbiger (Lancellotti and Vásquez 2000), the presence of these hooks has not been described (Fagetti 1970). Furthermore, the setation patterns in H. plana are significantly reduced on the antennule's peduncle; maxillule's coxal endite; maxila's endopod and scaphognathite; first maxilliped's endopod and epipod; second maxilliped's endopod and protopod; the third maxilliped; plus the absence of setation in the maxillue's protopod, and first maxilliped's coxal and basal endite (Fagetti 1970). 
Intraspecific seasonal variation

The seasonal variation in carapace length of $P$. barbiger (Fig. 3) could be related to the greater availability of food due to the occurrence of upwelling events along the central coast of Chile during the spring-summer months (Narváez et al. 2006; Thiel et al. 2007). Peaks of chlorophyll $a$ and phytoplankton registered in this region (Henríquez et al. 2007; Thomas 1999; Wieters et al. 2003) have been directly related to subsequent peaks of biodiversity and abundance of brachyuran zoea larvae and megalopae in the area (Palma 1976, 1980). Conditions like these should favor the storage of energy by larvae (Anger et al. 1989). Decapod larvae in particular need to have a minimum quantity of energetic resources available in order to molt to the next stage of development called the 'Point of Reserve Saturation' (PRS) (sensu Anger 1987; Anger and Dawirs 1981). PRS corresponds to the stored reserve substances in the hepatopancreas of the larva and is thought to be a precursor of hormones such as ecdysona (Anger and Dawirs 1981). When the larva has sufficient nourishment, the development time of each stage is shorter. The opposite occurs if the larva is subjected to periods of starvation; it cannot reach the PRS and delays the molting of a given stage (Anger 1987). This also implies greater losses of assimilated energy, due to exuviations, respiration and exertion (Anger 1995), which in turn can result in smaller megalopae. This is supported by the results obtained in our study, where the larger settled megalopae were obtained during a period of abundant nourishment caused by the proliferation of phytoplankton in the nearby upwelling area. The idea is also supported by the high rates of settlement registered by Pardo et al. (2007) between November and January (2004-2005), just after the highest levels of phytoplankton had been registered in the region (Thomas 1999; Wieters et al. 2003). Furthermore, weak rates of settlement were detected during winter (Pardo et al. 2007), possibly due to the fact that larval development had occurred under conditions of low primary productivity, meaning a higher energetic demand. Other factors such as temperature could also explain in part the observed size differences in megalopae. However, specific effects of temperature or productivity should be tested under controlled laboratory condition.

The identification of species is the foundation for more in-depth ecological studies. The challenge is then to obtain information on the different life-cycle stages of a species in its natural environment by integrating the traditional methods of laboratory cultivation with the collection of specimens in the wild and using tools such as DNA sequencing which have been demonstrated to be fast and efficient for crustaceans (Makinster et al. 1999; Pardo et al. 2009). Better morphological information on larvae and brachyuran development, which are susceptible of variation due to environmental factors, will augment the reach and precision of studies on larval dispersion, recruitment, and population ecology. The later correspond to areas of marine ecology, vital for the management and conservation of species with complex life cycles.

Acknowledgments We thank Elena Gessler and Fernando Ogalde for their active participation in this research, from sampling to drawing the megalopae. Thanks to Marcela Espinoza for helping with DNA extraction. LMP thanks the Direction de Investigation and Development (DID) of the Universidad Austral de Chile. A. T. P. thanks FONDECYT 1020499 for financial support. DV thanks to Iniciativa Científica Milenio Grant ICM P05-002 and CONICYT Grant PFB-23. All experimental work was conducted in Chile and complied with its existing laws.

\section{References}

Aljanabi SM, Martinez I (1997) Universal and rapid salt-extraction of high quality genomic DNA for PCR-based techniques. Nucleic Acids Res 25:4692-4693

Anger K (1987) The do threshold: a critical point in the larval development of decapod crustaceans. J Exp Mar Biol Ecol 108:15-30

Anger K (1995) The conquest of freshwater and land by marine crabs: adaptations in life-history patterns and larval energetic. J Exp Mar Biol Ecol 193:119-145

Anger K (2001) The biology of decapod crustacean larvae. Crustacean Issues 14:1-420

Anger K, Dawirs RR (1981) Influence of starvation on the larval development of Hyas araneus (Decapoda, Majidae). Helgol Meeresunters 34:287-311

Anger K, Harms J, Püschel C, Seeger B (1989) Physiological and biochemical changes during the larval development of a brachyuran crab reared under constant conditions in the laboratory. Helgol Meeresunters 43:225-244

Bas CC, Spivak ED, Anger K (2008) Variation in early developmental stages in two populations of an intertidal crab, Neohelice (Chasmagnathus) granulata. Helgoland Mar Res 62:393-401

Clarke PF, De Calazans D, Pohle G (1998) Accuracy and standarization of brachyuran larval description. Invertebr Repr Dev 33:127144

Cuesta JA, Luppi TA, Rodriguez A, Spivak ED (2002) Morphology of the megalopal stage of Chasmagnathus granulatus Dana, 1851 (Crustacea: Decapoda: Brachyura: Varunidae), with comments on morphological anomalies. Proc Biol Soc Wash 115:391-402

DeBrosse G, Sulkin S, Jamieson G (1990) Intraspecific morphological variability in megalopae of three sympatric species of the genus Cancer (Brachyura: Cancridae). J Crust Biol 10:315-329

Fagetti E (1970) Desarrollo larval en el laboratorio de Homalaspis plana (Milne-Edwards) (Crustacea Brachyura; Xanthidae). Rev Biol Mar Oceanogr 14:29-49

Filatov DA (2002) ProSeq: a software for preparation and evolutionary analysis of DNA sequence data sets. Mol Ecol Notes 2:621-624

Gebauer P, Paschke K, Moreno CA (2007) Reproductive biology and population parameters of Petrolisthes laevigatus (Anomura: Porcellanidae) in southern Chile: consequences on recruitment. J Mar Biol Assoc UK 87:729-734

Guerao G, Abelló P, Dos Santos A (2006) Morphological variability of the megalopa of Liocarcinus depurator (Brachyura: Portunidae) in Mediterranean and Atlantic populations. J Nat His 40:1851-1866

Hadfield M, Strathmann M (1996) Variability, flexibility and plasticity in life histories of marine invertebrates. Oceanol Acta 19:323334 
Henríquez LA, Daneri G, Muñoz C, Montero P, Veas RI, Palma AT (2007) Primary production and phytoplanktonic biomass in shallow marine environments of central Chile: effect of coastal geomorphology. Estuar Coast Shelf Sci 73:137-147

Ingle R (1992) Larval stages of Northeastern Atlantic crabs, an illustrated key. Chapman and Hall, Natural History Museum Publications, London

Lancellotti D, Vásquez JA (2000) Zoogeografía de macroinvertebrados bentónicos de la costa de Chile: contribución para la conservación marina. Rev Chil Hist Nat 73:99-129

Makinster JG, Roberts JE, Felder DL, Chlan CA, Boudreaux M, Neigel JE (1999) PCR amplification of a middle repetitive element detects larval stone crabs (Crustacea : Decapoda : Menippidae) in estuarine plankton samples. Mar Ecol Prog Ser 188:161-168

Mantelatto FL, Robles R, Felder DL (2007) Molecular phylogeny of the western Atlantic species of the genus Portunus (Crustacea, Brachyura, Portunidae). Zool J Linn Soc 150:211-220

Moksnes PO, Wennhage H (2001) Methods for estimating decapod larval supply and settlement: importance of larval behavior and development stages. Mar Ecol Prog Ser 209:257-273

Narváez DA, Navarrete SA, Largier J, Vargas CA (2006) Onshore advection of warm water, larval invertebrate settlement, and relaxation of upwelling off central Chile. Mar Ecol Prog Ser 309:159-173

Orensanz JM, Gallucci VF (1988) Comparative study of postlarval life-history schedules in four sympatric species of Cancer (Decapoda: Brachyura: Cancridae). J Crust Biol 8:187-220

Palma S (1976) Meroplancton de la región de Valparaíso. Cienc Tec Mar CONA 2:99-116

Palma S (1980) Larvas de crustáceos decápodos capturadas frente a la costa de Valparaíso. Invest Mar 8:129-144

Palma AT, Paschke K, Thiel M (2003a) Behavioral ecology of crustaceans. Rev Chil Hist Nat 76:147-148

Palma AT, Orrego C, Arraigada M (2003b) Crypsis in early benthic phases of brachyuran decapod crustaceans in central Chile. Rev Chi Hist Nat 76:149-156

Palma AT, Pardo LM, Veas RI, Cartes C, Silva M, Manriquez K, Díaz A, Muñoz C, Ojeda FP (2006) Coastal brachyuran decapods: settlement and recruitment under contrasting coastal geometry conditions. Mar Ecol Prog Ser 136:139-153

Palumbi SR (1996) Nucleic Acids II: the polymerase chain reaction. In: Hillis D, Moritz C, Mable B (eds) Molecular Systematics. Sinauer Associates Inc, Sunderland

Pardo LM, Palma AT, Prieto C, Sepulveda P, Valdivia I, Ojeda FP (2007) Processes regulating early post-settlement habitat use in a subtidal assemblage of brachyuran decapods. J Exp Mar Biol Ecol 344:10-22
Pardo LM, Ampuero D, Veliz D (2009) Using morphological and molecular tools to identify megalopae larvae collected in the field: the case of sympatric Cancer crabs. J Mar Biol Assoc UK 89(3):481-490

Pohle G, Fransozo A, Negreiros-Fransozo ML, Mantelatto LFM (1999) Larval Decapoda (Brachyura). In: Boltovskoy D (ed) South Atlantic zooplankton. Brackhuys Publishers, Leiden, pp 1281-1351

Retamal MA (1981) Catálogo ilustrado de los crustáceos decápodos de Chile. Gayana Zool 44:1-40

Schubart CD, Neigel JE, Felder DL (2000) Use of the mitochondrial $16 \mathrm{~S}$ rRNA gene for phylogenetic and population studies of Crustacea. Crust Issues 12:817-830

Shirley SM, Shirley TC, Rice SD (1987) Latitudinal variation in the Dungeness crab, Cancer magister: zoeal morphology explained by incubation temperature. Mar Biol 95:371-376

Tamura K, Dudley J, Nei M, Kumar S (2007) Molecular evolutionary genetics analysis (MEGA) software version 4.0. Mol Biol Evol 24:1596-1599

Thiel M, Macaya EC, Acuña E et al (2007) The Humboldt current system of northern and central Chile oceanographic processes, ecological interactions and socioeconomic feedback. Oceanogr Mar Biol Annu Rev 45:195-344

Thomas A (1999) Seasonal distribution of satellite-measured phytoplankton pigment concentration along de Chilean coast. J Geophys Res 104:25, 877-825, 890

Underwood A, Keough MJ (2001) Supply-side ecology the nature and consequences of variations in recruitment of intertidal organism. In: Berteness M, Gaines S, Hay M (eds) Marine Community Ecology. Sinauer Associates Inc, Sunderland, pp 183-200

Wahle RA, Steneck RS (1991) Recruitment habitats and nursery grounds of the American lobster Homarus americanus: a demographic bottleneck? Mar Ecol Prog Ser 69:231-243

Wehrtmann IS (1994) Larval production of the caridean shrimp, Crangon septemspinosa, in waters adjacent to Chesapeake Bay, USA, in relation to oceanographic conditions. Estuaries 17:508-517

Wehrtmann IS, Báez P (1997) Larvas y estadíos tempranos de desarrollo de crustáceos decápodos de Chile: descripciones publicadas. Invest Mar 25:263-276

Wehrtmann IS, López G (2003) Effects of temperature on the embryonic development and hatchling size of Betaeus emarginatus (Decapoda: Caridea: Alpheidae). J Nat Hist 37(18):2165-2178

Wieters E, Kaplan D, Navarrete SA, Sotomayor A, Largier J, Nielsen KJ, Veliz F (2003) Alongshore and temporal variability in chlorophyll a concentrations in Chilean nearshore waters. Mar Ecol Prog Ser 249:93-105 